With dis oynement de yelydys schulbe anoyntyd mediocrely with a lytyll slice at eve whane he goth to bedde $\&$ bynde it with a bonde tylle one de morowe.

This oynement cureth beste above alle de medicines in de wordle de bleryed yene \& de waterynge yene as wele in crokedmen as in oder, de weche I have often tymes provyd per certo. And after Johannem Damascenum in alle de sorowe of de yene \& ayenst defawte of de syghte ffurste it behoveth dyligently to consydre wheyther it be of hote cause or of colde, $\&$ yf it be of hote cause furste de mater scalbe deffyed cum surupo acetoso III dayes or IIII. And whanne de mater is dygeste ther schall thane be yoven furste a clystere mollificatyff de mor*.

That schall devoyd all de body \& dat schall be done with $\frac{\mathrm{v}}{2} \cdot 1$. of de a lectuarye made of de juse of rosys $\&$ made scharpe with Dyagredye. And thanne thou mayst sywerly werke with diverse remedyes in de seyd places after that de semeth to spede.

In colde cause de mater also schall furste be deffyed cum oximell diuretico i squillitico \& thane ferdermore de clysterye schalbe yoven as it is aforseyde $\&$ by de morowe alle de body schalbe purgyd cum $\frac{\mathrm{v}}{2}$ from Jorapige Galet. And afterwarde he schall procede foorth sywerly to de places of remedye \& spede wele . . .

Here ends the Ms. of the cure of the eyes.

To my regret I have not been able to compare the proof with the original, and so some errors in 15th century spelling have probably crept in.

\title{
ANNOTATION
}

\section{Ophthalmological "Moots" in the Curriculum}

It has often struck us that more use might be made in the teaching of ophthalmology of gatherings at stated intervals, say once a week, at which a subject is propounded and discussed by the students. Such meetings used to be held, we believe, in the Mayo Clinic in general surgery, and each student in turn would propose some question for discussion. Something similar to the "Moots," those post-prandial meetings for the cracking of legal nuts, which

\footnotetext{
* The remainder of this word is lost in the binding: it is probably "owe," making " morowe."
}

† The hierapicra of Galen. 
were revived some years ago at the Inns of Court, might be attempted at the eye hospitals in Great Britain. Such a plan would give the student confidence and would help to balance the knowledge acquired in the week in question. Ophthalmology offers plenty of subjects for serious discussion and if a wag once in a way were to ask the question whether strabismus came to England with William the Conqueror or was indigenous among the aborigines; such a light-hearted theme, incapable of proof, might help to vary the monotony. The arrangements might be left as a rule in the hands of the chief clinical assistants, and a weekly rota of attendances for the seniors, who would occupy the position of judge or arbiter, would let each man know beforehand the date of his attendance and would not add very greatly to his labours.

At the present time when the question of post-war reconstruction is being much discussed, we commend this idea to those in authority for what it is worth. On a small scale the scheme would have some affinity to the ophthalmic club which has been for many years a feature among the seniors in the profession.

\section{ABSTRACTS}

\section{I.-LENS}

(1) Fischer, F. P. (Utrecht).-Vitamin $B_{1}$ in the lens. (Ueber das Aneurin (Vitamin B1 der Linse). Ophthalmologica, Vol. XCVI, p. 219, 1939.

(1) Fischer recalls that Vitamin $B_{1}$ in the lens is present in the form of co-carboxylase, i.e., phosphorylated vitamin $B_{1}$. It is, therefore, effective not as a vitamin but as a ferment. It is the cause of the break-down of pyruvic acid, the accumulation of which characterizes the progressive turbidity of the lens and explains the deficiency of lactic acid in the cataractous lens.

\section{ARNOLd SORSBY.}

(2) Bencini (Siena).- The parathyroid and thyroid glands and the lens. (Sistema tiro-paratiroideo e cristallino). Boll. d'Ocul., June, 1939.

(2) There are four parathyroids in the dog, two situated on the upper end of the thyroid, two smaller, on the deep surface of the gland. This makes the removal difficult. Bencini operated on four dogs in 1934; all suffered from convulsions which were relieved by the injection of calcium and parathyroid hormone. In 